Please do not remove this page

RMIT

UNIVERSITY

\title{
Beyond Workchoices: negotiating a moment
}

\author{
Gardner AO, Margaret
}

https://researchrepository.rmit.edu.au/esploro/outputs/9921863925401341/filesAndLinks?institution=61RMIT_INST\&index=null

Gardner AO, M. (2008). Beyond Workchoices: negotiating a moment. The Economic and Labour Relations Review, 18(2), 33-42.

https://researchrepository.rmit.edu.au/discovery/fulldisplay/alma9921863925401341/61RMIT_INST:Resea rchRepository 


\section{| Beyond WorkChoices: Negotiating a Moment}

\section{Margaret Gardner *}

\section{Introduction}

Australian industrial relations was a curious beast for much of the twentieth century. For many it was the institutional equivalent of a marsupial - native to the Australian environment. It developed in the economic and social circumstances of the nineteenth century. Indeed the development and elaboration of the arbitral model of Australian industrial relations was one of the major social experiments of a vibrant, young and successful Australia.

It was at the high point of centralised wage fixation and trade union influence in the 1980s that the arbitral model finally faltered. In the success of the Accords and the transformation of the Australian economy in this period lay the beginning of its end. The destruction of this arbitral model took its first legislative form in the Keating government's Industrial Relations Reform Act 1993. From that time, Australia has been in the throes of reshaping its industrial relations to meet the new economic and social circumstances that the final decade of the twentieth century ushered in.

In policy terms, the martingale - the point at which policy may diverge from its previous path - occurred in 1993 with the Industrial Relations Reform Act. The major legislative changes the Howard government introduced in the Workplace Relations Act 1996 took advantage of the shift to a bargaining model enshrined in the Keating government's legislation to make subtle changes that would have had far-reaching consequences. Yet, before Australia could experience fully those effects, the unusual circumstances of an election in 2004 gave the Howard government control of the Senate as well as the House of Representatives. These circumstances led to a legislative change that has reopened the whole industrial relations system for review.

The industrial relations regime introduced in the Industrial Relations Reform Act had its roots in a notion of liberal collectivism. In contrast, the changes made in the Workplace Relations Act 1996 were in fact the Trojan horse for the development of a much more market individualist system. Nonetheless, these changes were sufficiently masked by the usual slow-unfolding impact of legislative change and by the continuing operation of state industrial relations systems, particularly in NSW and Queensland. As a result, the diminution of collective representation and influence looked like a societal change not a legislatively-induced one.

\footnotetext{
* Professor, RMIT University.
} 
However, the Workplace Relations Amendment (WorkChoices) Act 2005 nailed its colours to the mast. WorkChoices, in concert with the interpretation of the Constitutional powers that gave the Howard government the opportunity to effectively remove state jurisdictional coverage, made the new system truly national not federal. It clearly instituted a market individualist system and in doing so provided the opportunity for the union movement to reveal to workers the consequences of this new industrial relations. Reinstitution and reinforcement of the asymmetric power of the employer was now visible and pervasive. WorkChoices rejected liberal collectivism and did so through complex and coercive national legislation.

The voters replied in kind, repudiating that legislation in 2007 as comprehensively as they had repudiated the Industrial Peace Act when Prime Minister Stanley Bruce lost his seat in 1929. As a result, in 2008 the possibility of deliberate institutional change is now before us. Moreover there is room for real choice in the industrial relations system that we create through legislation. This is a 'Higgins moment' when we can lay down the base of a system that should serve for many decades.

In this paper I want to consider what the possible choices are, including the constraints or circumstances that should be considered in making this choice. How should Australia set its new course for this twenty-first century?

\section{From Arbitration to Collective Bargaining}

It is important to put this reflection in context, since what we have witnessed in Australia in the years at the end of the twentieth and the beginning of the twenty-first century is a strange mirror of the debates a century earlier. In that Higgins moment that ushered in the twentieth century, Australia famously created a 'new province for law and order' (Higgins 1922), a new way of recognising and ordering relations between employees and employers.

The Antipodean form of industrial relations created an arbitral model with the following features:

- a tribunal or tribunal system which is able to take hold of disputes between employers and employees without their consent and to resolve disputes and in doing so make principles for decisions;

- a restriction or prohibition on direct action to regulate the behaviour of the parties (and incidentally moderate their market power);

- decisions or awards that were binding on the parties and legally enforceable; and

- a mechanism for recognising the organisations or unions of workers and allowing them to represent the class of workers they organised (Mitchell 1980: 90-1; Gardner and Palmer 1997: 17).

The operation of this arbitral model changed over time as economic and social circumstances varied. The importance of the tribunals was typically countercyclical; that is, of less importance in a boom than in a bust. Over the first decades of the twentieth century, as with any regulatory forum, the limits of the 
legislation were tested and the operating styles and models of the tribunals and the relationship of the parties to them elaborated and stabilised.

The study of these relationships and their outcomes did not really grow until the 1950s when the significance of the way industrial relations was regulated became a source of academic interest in Australia, among other nations. When I began studying industrial relations, we had the benefit of those early investigations and the first strong current of the debate about whether Australia should move closer to the collective bargaining systems evident in the USA and UK and away from its peculiar institutional environment.

Arguments about collective bargaining versus arbitration, led by academics such as Joe Isaac (1979), Keith Hancock (1987) and John Niland (1978), underpinned much of my initial study of industrial relations. Essentially these arguments were about whether the arbitral model was flexible enough to deal with varying economic circumstances, nationally and at industry and enterprise levels. The first major policy outcomes that responded, albeit in different ways, to these debates emerged in the 1980s in the Hancock Report in 1984 at federal level, and in various state government inquiries, such as the Niland Green Paper in 1989 in NSW.

Although the recommendations of Hancock and Niland were quite different in kind, the outcomes led to 'modernisation' of the arbitral systems, rather than major change to the underlying features outlined above. What had been established in this debate, however, was the importance of providing mechanisms for responding to the needs and negotiations of the parties.

Over time, too, the federal system became more dominant. The emergence of national Accords between the union movement and the federal government in the 1980s brought a greater national focus to industrial relations. In the years following, this national focus was bolstered by a widening interpretation of constitutional powers that provided the basis for an increasingly dominant federal system.

\section{A Policy Martingale}

In the mid-1990s, two pieces of federal legislation changed fundamentally the arbitral model, which had underpinned industrial relations through the twentieth century. In 1993 the Industrial Relations Reform Act brought to the centre of the federal system a workplace-based bargaining regime.

The four major features of the 1993 changes were to:

- make enterprise agreements the centrepiece of the system, rather than national wage policy translated through industry and occupational awards;

- introduce an individual rights base in the legislation protecting a number of minimum conditions, where previously, conditions were embedded in awards;

- recast the tribunal's role as arbiter of the 'safety net' or minimum conditions and facilitator of bargaining, rather than regulator; and

- provide a new stream of agreements that could be made with limited union involvement. 
This legislation also provided a series of protections for union action and for individual employees. At the time of the introduction of this legislation, it was seen as a necessary set of changes to match a more open and flexible economy, to strengthen workplace-based representation by unions, and to provide a stronger national platform for protection of low-paid workers through setting minimum conditions in legislation.

However before the effects of these changes could be felt, this legislation gave way to the Workplace Relations Act. This law took the main pillars of this new workplace-based regime and introduced stronger individualist and nonunion elements.

The major changes were to:

- reduce the scope and impact of awards by specifying a limited number of 'allowable' matters. This had the effect of making enterprise agreements the dominant element; and

- change and reduce the role of unions and the tribunal by reducing protections for union organisation and action, and developing a separate nonunion stream of agreements at individual and enterprise level.

The arbitral model was a justice system, which set in place, through its tribunals and their decisions, a web of regulation (Strauss 1990; Gardner and Palmer 1997). It was a system in which unions had a role, through the tribunals and their awards and other decisions, in representing whole classes or groups of workers whether or not they were members.

The new regime of the 1990s changed decisively the role of tribunals and unions. Unions became representative only of their members and their ability to take action was reduced (Stewart 1992). The tribunals were given a limited role in facilitating agreements and making decisions in relation to individual rights. Legislative rights and conditions became the minima that once were set in awards of the Commission. And, agreements negotiated at enterprise or workplace level became the centre of the new industrial relations system.

Collective bargaining had arrived and displaced arbitration.

\section{WorkChoices}

When the Howard government won the 2004 election, its control of the Senate as well as the House of Representatives, allowed the introduction of new industrial relations legislation untouched by the need to accommodate amendments, such as those imposed in 1996. The Workplace Relations Amendment (WorkChoices) Act 2005-WorkChoices - took the now-established collective bargaining regime that was still working its way through the system and moved it decisively towards a more individualist and voluntarist system.

Some of the changes worked through the legal and economic trends established in the 1990s. Specifically, the formation of a dominant national system, rather than a federal system, through the use of the corporations power in the Constitution, has now established the federal government as the decisive authority for setting the industrial relations framework. 
Other changes reduced or eliminated protections of minimum conditions in place since the 1990s. Specifically, there was a reduction in the number of allowable matters that could be included in awards, and the specification of a very minimal set of five workplace conditions. These changes left almost no protection for vulnerable workers. Added to this were the major changes in unfair dismissal provisions that exempted companies with fewer than $100 \mathrm{em}$ ployees and allowed dismissal of any employee for reasons that included 'bona fide operational reasons.

The role of the Commission was vestigial; the role of setting a national minimum wage was allocated to a new body, the Australian Fair Pay Commission, and a plethora of new bodies, such as the Workplace Authority and the Workplace Ombudsman, came into being to administer different parts of the agreement-making process. Unions, now identified only as agents representing their members, had less room for action and faced a range of increased restrictions on their activities and industrial action. The enterprise and the individual were enshrined as the only levels at which agreements could be made.

WorkChoices, under the guise of choice and flexibility, reinforced the asymmetric power of the employer over employees. Those workers most vulnerable, typically unorganised and unrepresented by unions, had limited recourse and a minimal safety net. This was a system that rewarded market power, except if it was exercised through the collective organisations of workers. The legislation restricted a union with market power from exercising this power through building bargains across more than one employer or using its industrial might to secure better conditions for its members.

Thus, a century later, the Australian industrial relations system had been comprehensively reshaped and the principles and features that had shaped the Conciliation and Arbitration Act 1904 had been overturned. The only feature they shared was the restrictions on direct action. However the removal of this collective market power from workers was not significantly redressed by recourse to the means to resolve disputes or to provide redress to employer power much beyond what might be decided by the courts.

\section{Reflections on Reviewing Industrial Relations}

Before turning to what might be needed for Australian industrial relations in the future, I want to reflect briefly on some lessons I have drawn from a previous review of industrial relations legislation.

In 1998, I was appointed by the Queensland State government to chair a review of industrial relations legislation. The newly elected Beattie Labor government had committed itself to a review of its state legislation, which at that time mirrored the federal Workplace Relations Act. The Review's terms of reference asked for legislation that would balance the needs of the economy with fairness and equity, and balance collective and individual rights.

The legislation that became the Industrial Relations Act 1999 (Qld), accepted the premise established in the 1990s that negotiation of agreements by employers and unions or employees, rather than variation of awards through a tribunal, was at the core of industrial relations. Although bargaining arrangements were 
its centre, it retained a clear role for the arbitral tribunal in updating minimum conditions and resolving disputes where negotiations had broken down and for arbitration as a last resort.

It varied from federal legislation in providing for a wider range of collective agreements beyond enterprise level to deal with the circumstances that pertain in multi-employer projects and the like. The legislation also extended to provide for atypical workers, such as contractors and outworkers.

The Queensland legislation is in broad form closer to the framework of Keating's 1993 Reform Act than the successor federal legislation. It provided for: flexibility through the choice of agreements; protection of the vulnerable through a set of minimum conditions and recognising the range of atypical working arrangements that had arisen; and minimisation of lengthy industrial action through recourse to mediation and finally arbitration. And, unions retained a legitimate role in representation of, and negotiation on behalf of, workers.

The recommendations that formed the basis of the Queensland legislation were the result of agreement by representatives of employers, unions and government. As government has remained with the Labor Party, the legislation has remained in place since 1999 - with the only perturbation being the WorkChoices legislation, which effectively displaced a significant portion of state coverage.

The Queensland review responded to the changed economic and social circumstances of the late twentieth century and it represented the bipartisan political consensus that had emerged about the importance of bargaining over arbitration as the primary mechanism for managing relations between employers and employees.

There are three features of changed economic and social circumstances that remain cogent for this latest federal legislative review. They are the increasing scope of atypical employment arrangements in the workforce. Related to this, there are the increasing numbers of workers who are in circumstances where their employment arrangements are effectively individual. They are not represented by or not able to be reached by unions. Finally, there is a need for industrial arrangements that can reflect and adjust to the circumstances of different industries and enterprises.

It is not clear whether there is any room for greater political consensus about the role for unions as representatives of workers, about the range of minimum conditions (and their adjustment) that should be in place for all workers, and about a third party mediation and arbitration role to resolve major disputes. In the last decade or so, these three matters have been at the core of an ideological battle not only about industrial relations, but about what role there is for industrial relations legislation to ameliorate of the asymmetric power the employer holds in the employment relationship.

\section{Negotiating This Moment}

A new Labor Federal government has signalled that Australia's industrial relations system will change again. The Workplace Relations Amendment (Transi- 
tion to Forward with Fairness) Bill 2008 was introduced into the Australian Parliament on 13 February 2008, passed on 19 March 2008 and became effective on 27 March.

The key amendments in this Act remove the individual workplace agreements (AWAs) (subject to some transitional arrangements), introduce a nodisadvantage test that will provide a floor of conditions under new agreements, and allow the Commission back into the regulatory arena via award modernisation.

In this Transition Act, we see some of the initial directions of the future Australian industrial relations system. These provisions take us back to the legislation of the 1990s. In this change, we will see one further matter revealed and that is whether there remains a lack of bipartisan consensus on Australia's industrial relations system.

First, it is important that a stronger bipartisan consensus is formed. It is now clear on the basis of current constitutional interpretation that there is, in effect, only one industrial relations system in Australia and it is national. Without the checks and balances of a federal system, it is important that the regulation of employers and employees is not subject to whimsical change on the basis of the ideological predisposition of the party in power.

Second, the new legislation should therefore build on the current areas of agreement in the way of any good negotiation - beginning with 'yes' before assaying the 'nos'. To this end, I want to briefly outline the range of areas on which there is agreement. In the category of agreed foundations is that bargaining is central, that there is a need to specify minimum conditions to underpin the arrangements of all workers and particularly the vulnerable, and that unions are able to represent workers who are their members. There is also clear understanding that an independent body is needed to check that the legislation is complied with, that disputes over rights under the legislation can be dealt with, and that industrial action should be regulated.

There are matters to be resolved in each of these areas and in most we need broader debate than has been evident in the last decade or so. In attempting to provide flexibility in bargaining and moving away from industry or sectorwide awards, the enterprise became the focus. There is, however, no reason that the enterprise should be the focus for all bargaining. The rise of atypical employment, the fragmentation of some industries and consolidation of others, all would argue for recognising that, in some cases, multiple employers may wish to bargain together and, in others, individual enterprises. We should seek in the new legislation to recognise a range of bargaining arrangements.

The range of minimum conditions must be specified and a mechanism for their adjustment put in place that is at arm's length from government. The range of minima will be subject to debate between employers and unions, but there is, I would argue, a clear and accepted set generally in operation that goes beyond the minimum conditions specified in WorkChoices. In order to adjust these over time, there is a need to be at one remove from government and that requires an independent tribunal. 
If unions can and should represent their members, then there must be arrangements that allow them to gain access to potential new members and to their existing members in order to understand their aspirations and grievances. Unnecessary restrictions in these areas amount to practical repudiation of freedom of association.

There are a range of regulatory and compliance requirements. There is a need to adjust minimum conditions and pay, to check that legislative requirements for bargaining and agreements have been complied with and can be enforced and that breaches of the legislation are addressed. From the 1996 legislation through to WorkChoices, we have seen the proliferation of agencies to undertake these functions and a tendency to focus enforcement of rights and breaches of them on the courts.

There seems little reason to have so many agencies, alongside an independent tribunal that has had many decades' experience in dealing with adjustments to minimum wages and conditions, monitoring agreements and addressing compliance with industrial relations legislation. When mediation is the preferred method to deal with many commercial and private disputes, it appears unusual to step away from this method in the industrial relations arena.

The shift to bargaining as the core of the Australian industrial relations system means that there will be no return to the arbitral model as it developed in the last century. However, there is an argument for drawing on the experience of the Commission in taking an administrative role in adjusting minimum wages and conditions and in its accommodative role in resolving disputes as a last resort.

As we enshrine a stronger rights-based approach to employment arrangements, we would do well to use previous Australian experience to keep industrial relations as much as possible out of the courts and in the realm of pragmatic tribunal resolutions and determinations.

\section{Conclusion}

We face a moment in Australian industrial relations when we can negotiate an outcome that draws on our history but can respond flexibly to the future. We should aim for a framework that reconciles the demands of an open economy with a regard for social justice and fairness; that balances the rights of the individual and the collective; and has room for an independent forum to assist where negotiations break down or legislative requirements are breached.

There is no going back to the arbitral model. There is no way we can rely on collective agreements to address the multitude of employment arrangements we now confront. And so, to secure that fairness and social justice that should underpin our employment arrangements, and encourage employers to innovate and improve, we must rely on legislation that enshrines minimum conditions and rights.

No system where interests collide can proceed without a means to break deadlocks in negotiations or redress major asymmetry of market power. Here an independent tribunal has form and reason and there is a need to ensure that the ability of workers to organise collectively and have effective representa- 
tion is protected. Once these foundational matters seemed straightforward in Australian industrial relations. Only in the last decade have we had to reassert their importance. This is the moment to negotiate a new settlement for industrial relations - affirming that we have found our way to a liberal collectivist industrial relations regime.

\section{References}

Gardner, M. (1998) Review of Industrial Relations Legislation in Queensland, Department of Employment Training and Industrial Relations Queensland.

Gardner, M. and Palmer, G. (1997) Employment Relations, $2^{\text {nd }}$ Edition, Macmillan, Sydney.

Hancock, K. (1985) The Report of the Committee of Review into Australian Industrial Relations Law and Systems, AGPS, Sydney.

Hancock, K. (1987) 'Economics and the Reform of Industrial Relations', in G. W. Ford, J. M. Hearn, and R. Lansbury (eds) Australian Labour Relations: Readings $4^{\text {th }}$ Edition, Macmillan, Sydney, pp. 440-454.

Isaac, J. (1979) 'Professor Niland on Collective Bargaining and Compulsory Arbitration in Australia, Journal of Industrial Relations, 21(4), pp. 466-84.

March, J. and Olsen, J. (1989) 'The New Institutionalism: Organizational Factors in Political Life', American Political Science Review, 78(3), pp. 734-49.

Mitchell, R. (1989) 'State Systems of Conciliation and Arbitration: the Legal Origins of the Australasian Model', in S. Macintyre and R. Mitchell (eds) Foundations of Arbitration, Oxford University Press, Melbourne.

Niland, J. (1978) Collective Bargaining and Compulsory Arbitration in Australia, NSW University Press, Sydney.

Niland, J. (1989) Transforming Industrial Relations in NSW - A Green Paper, NSW Government Printer, Sydney.

Strauss, G. (1990) 'Toward the Study of Human Resources Policy’, in J. Chelius and J. Dworkin (eds) Reflections on the Transformation of Industrial Relations, IMLR Press/Rutgers University and The Scarecrow Press Inc., Metuche, New Jersey.

Stewart, A. (1992) 'Procedural Flexibility, Enterprise Bargaining and the Future of Arbitral Regulation', Australian Journal of Labour Law, 5(1), p. 101. 
